\title{
Activation of inflammasomes in adipose tissue of women with gestational
}

\section{diabetes}

\section{Martha Lappas}

Department of Obstetrics and Gynaecology, University of Melbourne, Victoria, Australia

Mercy Perinatal Research Centre, Mercy Hospital for Women, Heidelberg, Victoria, Australia

\section{Correspondence and Reprint Requests to:}

Dr Martha Lappas

Department of Obstetrics and Gynaecology, University of Melbourne

Mercy Hospital for Women, Level 4/163 Studley Road

Heidelberg, 3084, Victoria, Australia

Ph: 61-3-8458 4370; Fax: 61-3-8458 4380

E-mail: $\underline{\text { mlappas@unimelb.edu.au }}$ 


\section{ABSTRACT}

Gestational diabetes mellitus (GDM) is characterised by maternal peripheral insulin resistance, increased inflammation, and increasing levels of circulating free fatty acids (FFAs) and advanced glycation endproducts (AGEs). Caspase-1 is a key component of the inflammasome, which is activated upon cellular infection or stress to trigger the maturation IL-1 $\beta$, a pro-inflammatory cytokine that mediated insulin resistance. The aim of this study was to determine whether the inflammasome is activated in adipose tissue from women with gestational diabetes mellitus (GDM) and if it interferes with the insulin signalling pathway leading to the insulin resistance that is evident in GDM. Protein expression of active caspase- 1 and mature IL- $1 \beta$ secretion was increased in adipose tissue of women with GDM. Treatment of adipose tissue with IL-1 $\beta$ decreased insulinstimulated phosphorylation of IRS-1, GLUT-4 expression and glucose uptake. Low-grade inflammation (induced by LPS), the FFA palmitate and AGE conjugated to BSA (AGE-BSA), induced IL-1 $\beta$ secretion via inflammasome activation. In conclusion, the present findings describe an important role for adipose tissue inflammasome activation in the development of insulin resistance associated in pregnancies complicated by GDM.

Keywords: adipose tissue, GDM, inflammation, inflammasome, IL-1 $\beta$, insulin signalling 


\section{INTRODUCTION}

Diabetes in pregnancy is a major health issue globally, affecting up to $14 \%$ of all pregnancies (Kim, Berger and Chamany, 2007). Diabetes in pregnancy is defined as either pre-existing diabetes (type 1 and type 2) and gestational diabetes mellitus (GDM). GDM, characterised as any degree of glucose intolerance with first recognition during pregnancy, is the most common type of diabetes found in pregnancy. Of clinical importance, the rates of GDM are increasing worldwide, intensified with advancing maternal age, racial/ethnic disparities, and obesity (Ferrara, 2007). GDM is associated with substantial increased risks for both mother and infant (Dabelea, Hanson, Lindsay et al., 2000; Sobngwi, Boudou, Mauvais-Jarvis et al., 2003). Pregnancy complications include higher rates of macrosomia, shoulder dystocia, birth trauma, Caesarean birth and neonatal complications including jaundice and respiratory distress. The long term risks of exposure to GDM include increased risk of obesity, type 2 diabetes, insulin resistance, and other diseases. In the fetus, exposure to any form of diabetes results in a critically adverse fetal environment, enhancing susceptibility to a number of chronic diseases including obesity, diabetes, cardiovascular disease and certain cancers later in life.

Maternal adipose tissue plays an important role in fetal growth and development. The later part of normal human pregnancy is characterised by maternal hyperinsulinemia and insulin resistance, an adaptation that is required to meet the needs of the growing fetus (Buchanan and Xiang, 2005). In women with GDM however, peripheral insulin resistance is even more pronounced (Catalano, Nizielski, Shao et al., 2002; Colomiere, Permezel and Lappas, 2010), which results in greater substrate availability for fetal growth and development (Lain and Catalano, 2007). In addition, adipose tissue synthesises and secretes a number of cytokine hormones, which are dysregulated with GDM, that have been shown to correlate with fetal adiposity (Radaelli, Uvena-Celebrezze, Minium et al., 2006). 
What causes insulin resistance is not known. Many factors can enhance insulin resistance, including genetics, a sedentary lifestyle, obesity, and other conditions, such as chronic inflammation or infection. Of note, GDM is characterised by low-grade inflammation (endotoxemia), elevated circulating free fatty acids (FFA) and advanced glycation endproducts (AGEs) (Catalano et al., 2002; Lappas, Hiden, Desoye et al., 2011; Winzer, Wagner, Festa et al., 2004; Wolf, Sauk, Shah et al., 2004). Bacterial endotoxin lipopolysaccharide (LPS), the saturated FFA palmitate and AGEs activate toll like receptors (TLRs) to promote the production of pro-inflammatory cytokines from adipose tissue and/or adipocytes (Ajuwon and Spurlock, 2005; Creely, McTernan, Kusminski et al., 2007; Lappas, Permezel and Rice, 2007; Lappas, Yee, Permezel et al., 2005). These proinflammatory cytokines have been shown to attenuate insulin signalling in vitro and in vivo (Kahn, Hull and Utzschneider, 2006; Xu, Barnes, Yang et al., 2003). IL-1 $\beta$ is one of the principal inflammatory cytokines implicated in this process (Jager, Gremeaux, Cormont et al., 2007). In vitro, the inflammasome, and in particular its generation of active caspase-1, is required to process pro IL$1 \beta$ to an active, secreted molecule (Arend, Palmer and Gabay, 2008). It has been shown that in most systems, two signals are required for optimal IL-1 $\beta$ secretion (Bauernfeind, Ablasser, Bartok et al., 2011). Signal 1 is induced by TLR stimulation, leading to the synthesis of pro IL-1 $\beta$. Signal 2 is triggered by agents that can that can cause ionic perturbations (e.g. ATP) or pore forming toxins which induce the activation of caspase- 1 followed by IL-1 $\beta$ processing and release.

Recent evidence has demonstrated an important role for caspase- 1 mediated IL- $1 \beta$ in insulin resistance (Vandanmagsar, Youm, Ravussin et al., 2011). It is thus possible that in GDM, the activation of adipose tissue caspase- 1 may enhance the release of IL-1 $\beta$ that underlies the development of insulin resistance evident in this disease. Therefore, in this study, the hypotheses to be tested are that GDM is associated with increased caspase-1 activation in maternal adipose tissue, and that LPS, palmitate and AGE activate caspase-1-dependent IL-1 $\beta$ secretion from adipose tissue 
which can interfere with the insulin signalling pathway leading to insulin resistance in adipose tissue. 


\section{MATERIALS AND METHODS}

\subsection{Tissue collection and preparation}

Human omental adipose tissue was obtained (with the Research Ethics Committee of Mercy Health approval) from consenting women who delivered healthy, singleton infants at term ( $>37$ weeks gestation). Indications for Caesarean section were breech presentation and/or previous Caesarean section. Tissues were obtained within 15 min of delivery.

Omental adipose tissue was obtained from normal glucose tolerant (NGT) women and women with GDM. Women with any underlying medical conditions such as pre-existing diabetes, asthma, polycystic ovarian syndrome, preeclampsia and macrovascular complications were excluded. Women with GDM were diagnosed according to the criteria of the Australasian Diabetes in Pregnancy Society (ADIPS) by either a fasting venous plasma glucose concentrations of $\geq 5.5$ $\mathrm{mmol} / \mathrm{l}$ glucose, and/or $\geq 8.0 \mathrm{mmol} / \mathrm{l}$ glucose $2 \mathrm{~h}$ after a $75 \mathrm{~g}$ oral glucose load at approximately 28 weeks gestation. Women with GDM were managed by diet alone ( $n=8$ patients) or insulin in addition to diet ( $\mathrm{n}=8$ patients). Women were controlled by diet if their fasting glucose readings were maintained below $5.5 \mathrm{mmol} / \mathrm{l}$ over a 2 week period post diagnosis. Women with fasting glucose readings greater than $5.5 \mathrm{mmol} / \mathrm{l}$ were placed on insulin for optimal glucose control. All pregnant women were screened for GDM, and women participating in the normal group had a negative screen. The baseline characteristics for all patients used in this study are outlined in Table 1.

Adipose tissue was obtained within 10 min of delivery, thoroughly washed in ice-cold PBS to remove and blood. Dissected fragments were stored at $-80^{\circ} \mathrm{C}$ until assayed as detailed below. The clinical details of these patients are presented in Table 1. 


\subsection{Tissue explant culture}

For these studies, adipose tissue was obtained from NGT pregnant women, and tissue explants were performed as previously described (Barker, Lim, Georgiou et al., 2012; Lappas, Mitton and Permezel, 2010; Lappas, Permezel and Rice, 2005; Lappas, Permezel and Rice, 2004). Briefly, adipose tissues was finely diced and placed in DMEM at $37^{\circ} \mathrm{C}$ in a humidified atmosphere of $21 \%$ $\mathrm{O}_{2}$ and $5 \% \mathrm{CO}_{2}$ for $1 \mathrm{~h}$. Tissues were blotted dry on sterile filter paper and transferred to 24-well tissue culture plates $(100 \mathrm{mg}$ wet weight/well). The explants were incubated in $1 \mathrm{ml}$ DMEM containing $100 \mathrm{U} / \mathrm{ml}$ penicillin $\mathrm{G}$ and $100 \mu \mathrm{g} / \mathrm{ml}$ streptomycin. Tissues were incubated in the absence or presence of $1 \mu \mathrm{g} / \mathrm{ml} \mathrm{LPS}, 250 \mu \mathrm{M}$ palmitate (conjugated to BSA; PA-BSA) or $250 \mu \mathrm{M}$ glycated BSA (AGE-BSA) for $20 \mathrm{~h}$, followed by incubation with $5 \mathrm{mM}$ ATP for $2 \mathrm{~h}$. For the palmitate and AGE-BSA experiments, the control (basal) experiments were performed in DMEM containing BSA. Additional experiments were also performed whereby adipose tissue was pretreated with $10 \mu \mathrm{M}$ of the caspase-1 inhibitor Ac-YVAD-CHO or the $10 \mu \mathrm{M}$ of the P2X7 receptor antagonist KN-62 prior to the addition of LPS, palmitate or AGE-BSA. After the final incubation, medium was collected and assessment of cytokine concentrations was performed by ELISA. Each treatment was performed from at least four patients.

\subsection{Glucose uptake}

Adipose tissue explants were performed as detailed above and glucose uptake in adipose tissue was performed as previously described (Lappas, Andrikopoulos and Permezel, 2012). Briefly, after final incubation with treatment, tissues were pre-incubated in the absence or presence of $20 \mu \mathrm{M}$ cytochalasin B in Krebs buffer for 5 mins. 2-Deoxy-D-glucose (2DG) uptake was measured by adding $3 \mu \mathrm{Ci} / \mathrm{ml}\left[{ }^{14} \mathrm{C}\right]-2 \mathrm{DG}$ (Perkin Elmer) and $1 \mathrm{mM} 2 \mathrm{DG}$ to Krebs buffer containing $0.1 \%$ BSA (fatty acid free) and $0.1 \mu \mathrm{M}$ insulin for $20 \mathrm{~min}$. Tissues were then collected and washed in ice-cold PBS and solubilised for $4 \mathrm{~h}$ in $0.5 \mathrm{ml} 1 \mathrm{M} \mathrm{NaOH}$ at $60^{\circ} \mathrm{C}$. Tissues were neutralised with $0.5 \mathrm{ml} 1 \mathrm{M}$ 
$\mathrm{HCl}$ and then centrifuged at 15,000 g for $5 \mathrm{~min}$ to pellet insoluble material. The supernatant was transferred to a vial containing $3 \mathrm{ml}$ of liquid scintillation fluid. All samples were counted for radioactivity in a liquid scintillation counter. GLUT-specific glucose uptake was measured by subtracting values for $\left[{ }^{14} \mathrm{C}\right]-2 \mathrm{DG}$ uptake in the presence of $20 \mu \mathrm{M}$ cytochalasin $\mathrm{B}$. The rate of $\left[{ }^{14} \mathrm{C}\right]-$ 2DG transport was expressed in nanomoles per minute per milligram protein. Fold change was calculated relative to basal, which was set at 1 .

\subsection{RNA extraction and quantitative RT-PCR (qRT-PCR)}

Total RNA was extracted from tissues using TRIsure ${ }^{\mathrm{TM}}$ according to manufacturer's instructions (Bioline). RNA concentration and purity were measured using a NanoDrop ND1000 spectrophotometer (Thermo Scientific, Pittsburgh, PA). RNA was converted to cDNA using the SuperScript ${ }^{\circledR}$ VILO ${ }^{\text {TM }}$ cDNA synthesis kit (Invitrogen, Carlsbad, California, USA) according to the manufacturer's instructions. The cDNA was diluted fifty-fold, and $4 \mu \mathrm{l}$ of this was used to perform RT-PCR using SensiFAST ${ }^{\text {TM }}$ SYBR (Bioline) and $100 \mathrm{nM}$ of pre-designed and validated primers (QuantiTect primer assays; Qiagen). The RT-PCR was performed using a CFX384 Real-Time PCR detection system from Bio-Rad Laboratories. Average gene Ct values were normalised to the average GAPDH Ct values of the same cDNA sample. Fold differences were determined using the comparative $\mathrm{Ct}$ method, and shown as mean \pm SEM of relative gene expression. For the explant studies, there was a large variability of baseline values, which is normal for tissues derived from different patients. Thus, fold change was calculated relative to basal, which was set at 1 .

\subsection{Western blotting}

Tissue lysates and Western blotting were prepared as previously described (Lappas et al., 2005). Rabbit polyclonal anti-phosphorylated IRS-1 (ser641), rabbit polyclonal anti-IRS-1 (A-19), rabbit polyclonal anti-GLUT-4 (H-61), and rabbit polyclonal caspase-1 (sc-515) were purchased from Santa Cruz Biotechnology, Santa Cruz, CA, USA). Forty micrograms of protein was separated on 
polyacrylamide gels (Bio-Rad Laboratories, Hercules, CA, USA) and transferred to nitrocellulose. Protein expression was identified by comparison with the mobility of protein standard. Membranes were viewed and analysed using the Chemi-Doc system (Bio-Rad). Semi-quantitative analysis of the relative density of the bands in Western blots was performed using Quantity One 4.2.1 image analysis software (Bio-Rad). Data were corrected for background, normalised to $\beta$-actin and expressed as the ratio of the average of the NGT control. For the explant studies, fold change was calculated relative to basal, which was set at 1 .

\subsection{Cytokine immunoassays}

The release of IL-6 and IL-8 was performed by sandwich ELISA according to the manufacturer's instructions (Invitrogen, Carlsbad, California, USA). The concentration of IL-1 $\beta$ in the media was performed by sandwich ELISA according to the manufacturer's instructions (R\&D Systems). All data were corrected for total protein and expressed as either pg or ng per mg protein. The protein content of tissue homogenates was determined using BCA protein assay (Pierce, Rockford, USA), using BSA as a reference standard, as previously described (Lappas, Yee, Permezel et al., 2005). The calculated interassay and intraassay coefficients of variation $(\mathrm{CV})$ were all less than $10 \%$.

\subsection{Statistical analysis}

Statistics was performed on the normalised data unless otherwise specified. All statistical analyses were undertaken using GraphPad Prism (GraphPad Software, La Jolla, CA). Two sample comparisons, either a paired or unpaired Student's t-test was used to assess statistical significance between normally distributed data; otherwise, the nonparametric Mann-Whitney U (unpaired) or the Wilcoxon (matched pairs) tests were used. For all other comparisons, the homogeneity of data was assessed by the Bartlett test, and when significant, the data were logarithmically transformed before 
further analysis using a one-way ANOVA (using LSD correction to discriminate among the means). Statistical significance was ascribed to $P$ value $<0.05$. Data were expressed as mean \pm standard error of the mean (SEM). 


\section{RESULTS}

\subsection{IL-1 $\beta$ is increased in adipose tissue from women with GDM}

Adipose tissue was obtained from 9 women with NGT and 16 women with GDM (n=8 diet- and $\mathrm{n}=8$ insulin-controlled GDM). Demographic data of all participants involved in this study are summarised in Table 1. QRT-PCR performed on adipose tissue biopsies showed no difference in IL-1 $\beta$ gene expression between NGT and GDM women (Figure 1A). The effect of GDM on IL-1 $\beta$ secretion was assessed by ELISA. As shown in Figure 1B, the release of mature IL-1 $\beta$ into the incubation medium was significantly greater from adipose tissue obtained from GDM women. There was no significant difference in IL-1 $\beta$ expression and release between women with GDM who were managed by dietary modification alone compared with women who were treated with insulin.

\subsection{IL-1 $\beta$ impairs insulin signalling in pregnant adipose tissue}

In women with GDM, GLUT-4 and subsequent glucose uptake is lower in adipose tissue (Colomiere et al., 2010; Garvey, Maianu, Zhu et al., 1993). IL-1 $\beta$ is one of the principal inflammatory cytokines implicated in the attenuation of insulin signalling in vitro and in vivo (Jager et al., 2007). Thus, the next aim of this study was to determine the effect of IL-1 $\beta$ on insulin signalling in pregnant adipose tissue; the data is presented in Figure 2. IL-1 $\beta$ significantly attenuated phosphorylated IRS-1 protein expression (Figure 2A), GLUT-4 mRNA expression (Figure 2B), GLUT-4 protein expression (Figure 2C) and 2DG uptake (Figure 2D).

\subsection{Increased caspase-1 activation in adipose tissue from women with GDM}

Processing of the precursor protein pro-IL-1 $\beta$ to biologically active mature IL-1 $\beta$ requires activated caspase-1. Thus, the next aim of this study was to determine the effect of GDM on caspase-1 
activation in adipose tissue. QRT-PCR performed on adipose tissue biopsies showed no difference in caspase-1 mRNA expression between NGT and GDM women (Figure 3A). Western blotting was used to detect endogenous full-length (p45 subunit) and activated (p35 and p10 fragment) human caspase-1. Caspase-1 p35 and p10 expression was significantly higher in adipose tissue obtained from women with GDM compared to NGT (Figure 3B). There was no effect of GDM on full-length caspase-1 expression. There was no significant difference in caspase-1 expression between women with GDM who were managed by dietary modification alone compared with women who were treated with insulin.

\subsection{ATP induces IL-1ß secretion from adipose tissue primed with LPS, palmitate and}

\section{glycated BSA}

In most cells, the processing and production of IL-1 $\beta$ requires two signals. The first signal induces the transcription and translation of pro-IL- $1 \beta$ via NF- $\kappa B$. A second signal, such as ATP, is required to activate caspase- 1 mediated IL- $1 \beta$ production. Thus, the first part of this next aim was to determine if the TLR ligands bacterial endotoxin LPS, the saturated FFA palmitate (conjugated to BSA) and AGE-BSA induce IL-1 $\beta$ transcription via NF- $\kappa B$. As shown in Figures 4A-C, treatment of adipose tissue with LPS, palmitate and AGE-BSA significantly increased IL- $1 \beta$ gene transcription. This increase in IL-1 $\beta$ mRNA expression was significantly attenuated in the presence of the NF-kB inhibitor BAY 11-7082.

The next part of this aim was to determine the effect of LPS, PA-BSA and AGE-BSA, in the absence or presence of ATP, on IL-1 $\beta$ secretion. As expected, LPS, PA-BSA and AGE-BSA induced an increase in IL-1 $\beta$ transcription (Figure 5A,D,G). There was, however, no additional effect of ATP on IL-1 $\beta$ gene expression. On the other hand, although LPS, PA-BSA and AGE-BSA alone increased IL-1 $\beta$ release, the addition of ATP significantly augmented IL- $1 \beta$ release (Figure $5 \mathrm{~B}, \mathrm{E}, \mathrm{H})$. The specificity for IL- $1 \beta$ production was assessing by analysing IL- 6 secretion. In contrast 
to IL-1 $\beta$, there was no additive effect of ATP on LPS or AGE-BSA induced IL-6 release (Figures 5C,I). Of note, there was no effect of PA-BSA on IL-6 secretion (Figure 5F). Similar results were obtained for IL-8 production (data not shown).

\subsection{Caspase-1 regulates ATP induced IL-1 $\beta$ secretion from adipose tissue primed with LPS, PA-BSA or AGE-BSA}

The next aim was of this study was to determine if caspase- 1 is involved in the genesis of ATP induced IL-1 $\beta$ secretion in LPS, PA-BSA or AGE-BSA primed tissues. Tissues were pre-treated with the cell-permeable, irreversible caspase-1 peptide inhibitor Ac-Tyr-Val-Ala-Asp-CHO (AcYVAD-CHO; $10 \mu \mathrm{M}$ ) for $60 \mathrm{~min}$, and then incubated in the presence of $1 \mu \mathrm{g} / \mathrm{ml} \mathrm{LPS}, 250 \mu \mathrm{M}$ PABSA or $0.25 \mathrm{mg} / \mathrm{ml}$ AGE-BSA for $18 \mathrm{~h}$, followed by incubation with $5 \mathrm{mM}$ ATP for $2 \mathrm{~h}$. Mature IL-1 $\beta$ into the incubation media was assessed by ELISA. As expected, ATP induced a significant increase in IL-1 $\beta$ secretion in adipose tissue primed with LPS (Figure 6A), PA-BSA (Figure 6C) and AGE-BSA (Figure 6E). Pre-treatment with Ac-YVAD-CHO significantly attenuated the LPS, PA-BSA and AGE-BSA enhanced increase in IL-1 $\beta$ release. In contrast to IL-1 $\beta$ production, IL-6 (Figures 6B,D,F) and IL-8 (data not shown) production was not significantly affected by AcYVAD-CHO.

\subsection{ATP induces mature IL-1 $\beta$ secretion via the P2X7 receptor from adipose tissue primed with LPS, PA-BSA or AGE-BSA}

ATP requires signalling through the P2X7 receptor to induce caspase-1 mediated IL- $1 \beta$ processing and release (Franchi, Kanneganti, Dubyak et al., 2007; Pelegrin, Barroso-Gutierrez and Surprenant, 2008; Kahlenberg, Lundberg, Kertesy et al., 2005). Thus, the next aim of this study was to determine the effect of the $\mathrm{P} 2 \mathrm{X} 7$ receptor antagonist KN-62 on IL-1 $\beta$ release. As expected, ATP induced a significant increase in IL-1 $\beta$ secretion in adipose tissue primed with LPS (Figure 7A), PA-BSA (Figure7C) and AGE-BSA (Figure 7E). Pre-treatment with KN-62 significantly attenuated 
the LPS, PA-BSA and AGE-BSA enhanced increase in IL-1 $\beta$ release. There was no effect of KN-

62 on IL-6 (Figures 7B,D,F) and IL-8 (data not shown) production. 


\section{DISCUSSION}

This study, for the first time, demonstrates that the expression of active caspase- 1 expression and mature IL-1 $\beta$ production is increased in adipose tissue obtained from women with GDM when compared to BMI matched NGT women. LPS, palmitate and AGE-BSA induced the maturation of IL-1 $\beta$ via caspase- 1 activation. Treatment of pregnant adipose tissue with IL- $1 \beta$ resulted in a decrease in insulin stimulated glucose uptake. Collectively, this data suggests that IL-1 $\beta$ may contribute to the pathophysiology of GDM.

$\mathrm{IL}-1 \beta$ is one of the primary inflammatory cytokines implicated in type 2 diabetes. Gene expression for IL-1 $\beta$ is greater than 100 -fold higher in $\beta$-cells from patients with type 2 diabetes than from patients without diabetes (Boni-Schnetzler, Thorne, Parnaud et al., 2008). It elevates risk for type 2 diabetes (Spranger, Kroke, Mohlig et al., 2003) by inducing insulin resistance in insulin-sensitive cells (Jager et al., 2007). In support of these in vitro effects, clinical studies have reported that either IL-1 receptor antagonist (IL-1RA) or IL-1 $\beta$ antibody can help treat type 2 diabetes (Larsen, Faulenbach, Vaag et al., 2007; Mandrup-Poulsen, Pickersgill and Donath, 2010). In addition, a very recently published study has shown that gevokizumab (also known as XOMA 052), an anti-IL-1 $\beta$ monoclonal antibody, prevents IL-1 $\beta$-mediated insulin resistance in 3T3-L1 adipocytes (Handa, Vanegas, Maddux et al., 2013). Clinically, gevokizumab improved glycaemia, possibly via restored insulin production and action, and reduced inflammation in patients with type 2 diabetes (Cavelti-

Weder, Babians-Brunner, Keller et al., 2012). In agreement with these studies demonstrating an important role for IL-1 $\beta$ in insulin action, this study demonstrates that IL-1 $\beta$ significantly inhibits insulin signalling in adipose tissue from pregnant women, as evidenced by decreased phosphorylated IRS-1, GLUT-4 expression and glucose uptake. Thus, IL-1 $\beta$ may be one of the 
mechanisms causing the peripheral insulin resistance observed in GDM (Colomiere et al., 2010; Garvey et al., 1993).

In vitro, the generation of active caspase-1, is absolutely required to produce bioactive IL-1 $\beta$. Caspase- 1 is produced from the constitutively expressed $45 \mathrm{kD}$ pro-enzyme, procaspase, which is also found in the cytoplasm. Activation of caspase-1 requires post-translational processing; the first cleavage event generates p10 and p35 subunits. The p35 can then be further cleaved generating the mature p20 subunit. In this study, GDM was associated with increased caspase-1 activation. Specifically, when compared to BMI-matched NGT women, the p10 and p35 subunits of caspase-1 were increased in adipose tissue obtained from women with GDM. Similarly, caspase-1 is activated in retinas of diabetic mice and diabetic patients (Mohr, Xi, Tang et al., 2002) and in kidneys of STZ-treated rats (Wang, Pan, Zhang et al., 2012).

In most cells, optimal IL-1 $\beta$ production is dependent on two separate signals (Schroder and Tschopp, 2010). Signal-1 is mediated by stimulation of pattern recognition receptors (e.g. TLRs) resulting in the activation of NF- $\mathrm{KB}$ and transcription of its target genes including pro IL-1 $\beta$. Signal 2, mediated by damage associated molecular patterns (DAMPs) such as high ATP, leads to caspase1 activation and subsequent secretion of mature IL-1 $\beta$. Given that GDM was associated with increased caspase- 1 activation and IL-1 $\beta$ production, studies were then undertaken to determine if caspase-1 regulates IL- $1 \beta$ secretion in the context of GDM. For these studies, low-dose LPS, the saturated FFA palmitate and AGE-BSA were used as they have been shown to be increased in pregnancies complicated by GDM (Catalano et al., 2002; Lappas et al., 2011; Winzer et al., 2004; Wolf et al., 2004).

Previous studies using non-pregnant tissues have shown that LPS, palmitate and AGEs can promote inflammatory responses by directly engaging TLRs and inducing NF- $\mathrm{BB}-$ dependent gene 
transcription (Ajuwon and Spurlock, 2005; Creely et al., 2007; Lappas et al., 2007; Lappas et al., 2005). Likewise, in this study, LPS, palmitate and AGE-BSA increased IL- $1 \beta$ gene expression in pregnant adipose tissue; an effect that could be abrogated by an inhibitor of NF- $\kappa \mathrm{B}$ activation. Moreover, although LPS, palmitate and AGE-BSA could induce IL-1 $\beta$ secretion, ATP further significantly increased IL-1 $\beta$ secretion at least 3-fold. There was, however, no additive effect of ATP on IL- $\beta$ mRNA expression, suggesting that the increase in IL- $1 \beta$ secretion is independent of IL-1 $\beta$ gene transcription. In fact, this increase was dependent on caspase- 1 activation as the specific inhibitor of caspase-1 activity Ac-YVAD-CHO significantly attenuated ATP induced mature IL-1 $\beta$ secretion in tissues primed with LPS, palmitate and AGE-BSA. Notably, the specificity was demonstrated by showing no effect ATP or the caspase- 1 inhibitor on IL-6 and IL-8 production. Taken together, these results show that in adipose tissue, two signals are required to increase the release of mature IL-1 $\beta$. The first signal is mediated by LPS, FFA or AGE-BSA, which induces IL$1 \beta$ transcription via NF- $\kappa \mathrm{B}$. This also results in moderate IL-1 $\beta$ secretion. However, a second signal, such as ATP, is required for activation of caspase-1, and caspase-1 mediated IL-1 $\beta$ secretion.

ATP is thought to activate the caspase- 1 mediated IL- $1 \beta$ production through binding to the ionotropic receptor P2X7 (Franchi et al., 2007; Pelegrin et al., 2008; Kahlenberg et al., 2005). The binding of ATP to the $\mathrm{P} 2 \mathrm{X} 7$ receptor leads to cytolytic pore formation on the cell surface resulting in the rapid efflux of potassium out of the cell. It has been shown that inhibition of ATP binding to $\mathrm{P} 2 \mathrm{X} 7$ or in cells deficient in the P2X7 receptor, the amount of secreted IL-1 $\beta$ is low or absent (Solle, Labasi, Perregaux et al., 2001). Thus, in this study the P2X7 receptor antagonist KN-62 was used to determine if ATP regulates caspase- 1 activation and IL-1 $\beta$ secretion via the P2X7 receptor. The results revealed that in tissues primed with LPS, palmitate or AGE-BSA, ATP induced caspase1 activation and IL-1 $\beta$ secretion was significantly attenuated in the presence of KN-62. These 
results suggest that ATP regulates the caspase-1 mediated IL-1 $1 \beta$ production in pregnant adipose tissue via the $\mathrm{P} 2 \mathrm{X} 7$ receptor.

Activation of caspase- 1 occurs following assembly of the inflammasome. In particular, other studies have also reported an important role for the NLRP3 inflammasome in insulin resistance and glucose metabolism (Tack, Stienstra, Joosten et al., 2012). Studies in mice have shown that genetic ablation of NLRP3 improved insulin sensitivity and glucose homeostasis (Vandanmagsar et al., 2011;

Stienstra, Joosten, Koenen et al., 2010). In humans, NLRP3 inflammasome activation in adipose tissue of obese males is related to insulin resistance and impaired glucose metabolism (Goossens, Blaak, Theunissen et al., 2012). Additionally, weight-loss has been shown to reduce adipose tissue NLRP3 and IL-1 $\beta$ gene expression, and improved insulin resistance in obese subjects with type 2 diabetes (Vandanmagsar et al., 2011). In vitro, high glucose activates the NLRP3 inflammasome in human primary adipocytes (Koenen, Stienstra, van Tits et al., 2011). Multiple other NLRinflammasome complexes have also been discovered in recent years, such as AIM2, caspase-11, and caspase-8 inflammasomes (Maelfait, Vercammen, Janssens et al., 2008; Hornung, Ablasser, Charrel-Dennis et al., 2009; Lamkanfi and Dixit, 2012). The role of NLR-inflammasome complexes warrants further investigation in GDM.

There are a number of limitations of this study. Firstly, the investigated subjects were obese when they entered pregnancy. Given that chronic inflammation is evident in the pre-gravid obese state, it is possible that obesity itself may impact the results and thus the conclusions. It would be of interest to evaluate the expression of IL-1 $\beta$ and caspase- 1 in non-obese individuals. Secondly, only one concentration of IL-1 $\beta$ was used to determine effects on the insulin signalling pathway and glucose uptake. It is possible that higher and lower concentrations of IL-1 $\beta$ may induce a different response. Notwithstanding these limitations, this is the first study to demonstrate increased inflammasome activation in adipose tissue of obese women with GDM. 
In conclusion, the present findings delineate the importance of adipose tissue inflammasome in the development of insulin resistance in pregnancies complicated by GDM. The data presented in this study show that adipose tissue obtained from women with GDM is associated with increased caspase- 1 activation and release of the pro-inflammatory cytokine IL- $1 \beta$ which impairs insulin signalling in adipose tissue. Additionally, inflammation, FFAs and AGEs, which are increased in GDM pregnancies, can activate caspase-1 mediated IL-1 $\beta$ production, which prevents normal insulin signalling in adipose tissue. These results indicate that the caspase-1/IL-1 $\beta$ signalling pathway plays an important role in the pathophysiology of GDM. 


\section{ACKNOWLEDGEMENTS}

The following are gratefully acknowledged: Gillian Barker (Department of Obstetrics and Gynaecology, University of Melbourne) for her excellent technical assistance; clinical Research Midwives Gabrielle Fleming, Renee Grant and Debra Jinks for sample collection; and the Obstetrics and Midwifery staff of the Mercy Hospital for Women for their co-operation.

\section{FUNDING}

Dr. Martha Lappas is supported by a Career Development Fellowship by the National Health and Medical Research Council (NHMRC; grant no. 1047025). This work was funded by grants from Diabetes Australia Research Trust (DART) and the Medical Research Foundation for Women and Babies.

\section{DISCLOSURE SUMMARY}

The author has nothing to declare. 


\section{REFERENCES}

[1] Kim, C., Berger, D.K. and Chamany, S., 2007. Recurrence of gestational diabetes mellitus: a systematic review, Diabetes Care. 30, 1314-9.

[2] Ferrara, A., 2007. Increasing prevalence of gestational diabetes mellitus: a public health perspective, Diabetes Care. 30 Suppl 2, S141-6.

[3] Dabelea, D., Hanson, R.L., Lindsay, R.S., Pettitt, D.J., Imperatore, G., Gabir, M.M., Roumain, J., Bennett, P.H. and Knowler, W.C., 2000. Intrauterine exposure to diabetes conveys risks for type 2 diabetes and obesity: a study of discordant sibships, Diabetes. 49, 2208-11.

[4] Sobngwi, E., Boudou, P., Mauvais-Jarvis, F., Leblanc, H., Velho, G., Vexiau, P., Porcher, R., Hadjadj, S., Pratley, R., Tataranni, P.A., Calvo, F. and Gautier, J.F., 2003. Effect of a diabetic environment in utero on predisposition to type 2 diabetes, Lancet. 361, 1861-5.

[5] Buchanan, T.A. and Xiang, A.H., 2005. Gestational diabetes mellitus, J Clin Invest. 115, 485-91.

[6] Catalano, P.M., Nizielski, S.E., Shao, J.H., Preston, L., Qiao, L.P. and Friedman, J.E., 2002. Downregulated IRS-1 and PPAR gamma in obese women with gestational diabetes: relationship to FFA during pregnancy, American Journal of Physiology-Endocrinology and Metabolism. 282, E522-E533.

[7] Colomiere, M., Permezel, M. and Lappas, M., 2010. Diabetes and obesity during pregnancy alter insulin signalling and glucose transporter expression in maternal skeletal muscle and subcutaneous adipose tissue, J Mol Endocrinol. 44, 213-23.

[8] Lain, K.Y. and Catalano, P.M., 2007. Metabolic changes in pregnancy, Clin Obstet Gynecol. 50, 938-48.

[9] Radaelli, T., Uvena-Celebrezze, J., Minium, J., Huston-Presley, L., Catalano, P. and Hauguel-de Mouzon, S., 2006. Maternal interleukin-6: marker of fetal growth and adiposity, J Soc Gynecol Investig. 13, 53-7.

[10] Lappas, M., Hiden, U., Desoye, G., Froehlich, J., Hauguel-de Mouzon, S. and Jawerbaum, A., 2011. The role of oxidative stress in the pathophysiology of gestational diabetes mellitus, Antioxid Redox Signal. 15, 3061-100.

[11] Winzer, C., Wagner, O., Festa, A., Schneider, B., Roden, M., Bancher-Todesca, D., Pacini, G., Funahashi, T. and Kautzky-Willer, A., 2004. Plasma adiponectin, insulin sensitivity, and subclinical inflammation in women with prior gestational diabetes mellitus, Diabetes Care. 27, 1721-1727. 
[12] Wolf, M., Sauk, J., Shah, A., Smirnakis, K.V., Jimenez-Kimble, R., Ecker, J.L. and Thadhani, R., 2004. Inflammation and glucose intolerance - A prospective study of gestational diabetes mellitus, Diabetes Care. 27, 21-27.

[13] Ajuwon, K.M. and Spurlock, M.E., 2005. Palmitate activates the NF-kappa B transcription factor and induces IL-6 and TNF alpha expression in 3T3-L1 adipocytes, Journal of Nutrition. 135, 1841-1846.

[14] Creely, S.J., McTernan, P.G., Kusminski, C.M., Fisher, F.M., Da Silva, N.F., Khanolkar, M., Evans, M., Harte, A.L. and Kumar, S., 2007. Lipopolysaccharide activates an innate immune system response in human adipose tissue in obesity and type 2 diabetes, American Journal of Physiology-Endocrinology and Metabolism. 292, E740-E747.

[15] Lappas, M., Permezel, M. and Rice, G.E., 2007. Advanced glycation endproducts mediate pro-inflammatory actions in human gestational tissues via nuclear factor-kappaB and extracellular signal-regulated kinase 1/2, J Endocrinol. 193, 269-77.

[16] Lappas, M., Yee, K., Permezel, M. and Rice, G.E., 2005. Sulfasalazine and BAY 11-7082 interfere with the nuclear factor-kappa B and I kappa B kinase pathway to regulate the release of proinflammatory cytokines from human adipose tissue and skeletal muscle in vitro, Endocrinology. 146, 1491-7.

[17] Kahn, S.E., Hull, R.L. and Utzschneider, K.M., 2006. Mechanisms linking obesity to insulin resistance and type 2 diabetes, Nature. 444, 840-846.

[18] Xu, H.Y., Barnes, G.T., Yang, Q., Tan, Q., Yang, D.S., Chou, C.J., Sole, J., Nichols, A., Ross, J.S., Tartaglia, L.A. and Chen, H., 2003. Chronic inflammation in fat plays a crucial role in the development of obesity-related insulin resistance, Journal of Clinical Investigation. 112, 1821-1830.

[19] Jager, J., Gremeaux, T., Cormont, M., Le Marchand-Brustel, Y. and Tanti, J.F., 2007. Interleukin-1 beta-induced insulin resistance in adipocytes through down-regulation of insulin receptor substrate-1 expression, Endocrinology. 148, 241-251.

[20] Arend, W.P., Palmer, G. and Gabay, C., 2008. IL-1, IL-18, and IL-33 families of cytokines, Immunological Reviews. 223, 20-38.

[21] Bauernfeind, F., Ablasser, A., Bartok, E., Kim, S., Schmid-Burgk, J., Cavlar, T. and Hornung, V., 2011. Inflammasomes: current understanding and open questions, Cell Mol Life Sci. 68, 765-83.

[22] Vandanmagsar, B., Youm, Y.H., Ravussin, A., Galgani, J.E., Stadler, K., Mynatt, R.L., Ravussin, E., Stephens, J.M. and Dixit, V.D., 2011. The NLRP3 inflammasome instigates obesity-induced inflammation and insulin resistance, Nature Medicine. 17, 179-U214. 
[23] Barker, G., Lim, R., Georgiou, H.M. and Lappas, M., 2012. Omentin-1 is decreased in maternal plasma, placenta and adipose tissue of women with pre-existing obesity, PLoS One. 7, e42943.

[24] Lappas, M., Mitton, A. and Permezel, M., 2010. In response to oxidative stress, the expression of inflammatory cytokines and antioxidant enzymes are impaired in placenta, but not adipose tissue, of women with gestational diabetes, J Endocrinol. 204, 75-84.

[25] Lappas, M., Permezel, M. and Rice, G.E., 2005. Leptin and adiponectin stimulate the release of proinflammatory cytokines and prostaglandins from human placenta and maternal adipose tissue via nuclear factor-kappaB, peroxisomal proliferator-activated receptorgamma and extracellularly regulated kinase 1/2, Endocrinology. 146, 3334-42.

[26] Lappas, M., Permezel, M. and Rice, G.E., 2004. Release of proinflammatory cytokines and 8-isoprostane from placenta, adipose tissue, and skeletal muscle from normal pregnant women and women with gestational diabetes mellitus, J Clin Endocrinol Metab. 89, 562733.

[27] Lappas, M., Andrikopoulos, S. and Permezel, M., 2012. Hypoxanthine-xanthine oxidase down-regulates GLUT1 transcription via SIRT1 resulting in decreased glucose uptake in human placenta, J Endocrinol. 213, 49-57.

[28] Lappas, M., Yee, K., Permezel, M. and Rice, G.E., 2005. Release and regulation of leptin, resistin and adiponectin from human placenta, fetal membranes, and maternal adipose tissue and skeletal muscle from normal and gestational diabetes mellitus-complicated pregnancies, J Endocrinol. 186, 457-65.

[29] Garvey, W.T., Maianu, L., Zhu, J.H., Hancock, J.A. and Golichowski, A.M., 1993. Multiple defects in the adipocyte glucose transport system cause cellular insulin resistance in gestational diabetes. Heterogeneity in the number and a novel abnormality in subcellular localization of GLUT4 glucose transporters, Diabetes. 42, 1773-85.

[30] Franchi, L., Kanneganti, T.D., Dubyak, G.R. and Nunez, G., 2007. Differential requirement of P2X7 receptor and intracellular $\mathrm{K}+$ for caspase- 1 activation induced by intracellular and extracellular bacteria, Journal of Biological Chemistry. 282, 18810-18818.

[31] Pelegrin, P., Barroso-Gutierrez, C. and Surprenant, A., 2008. P2X(7) receptor differentially couples to distinct release pathways for IL-1 beta in mouse macrophage, Journal of Immunology. 180, 7147-7157.

[32] Kahlenberg, J.M., Lundberg, K.C., Kertesy, S.B., Qu, Y. and Dubyak, G.R., 2005. Potentiation of caspase- 1 activation by the P2X7 receptor is dependent on TLR signals and requires NF-kappa B-driven protein synthesis, Journal of Immunology. 175, 7611-7622. 
[33] Boni-Schnetzler, M., Thorne, J., Parnaud, G., Marselli, L., Ehses, J.A., Kerr-Conte, J., Pattou, F., Halban, P.A., Weir, G.C. and Donath, M.Y., 2008. Increased interleukin (IL)1beta messenger ribonucleic acid expression in beta -cells of individuals with type 2 diabetes and regulation of IL-1beta in human islets by glucose and autostimulation, J Clin Endocrinol Metab. 93, 4065-74.

[34] Spranger, J., Kroke, A., Mohlig, M., Hoffmann, K., Bergmann, M.M., Ristow, M., Boeing, H. and Pfeiffer, A.F., 2003. Inflammatory cytokines and the risk to develop type 2 diabetes: results of the prospective population-based European Prospective Investigation into Cancer and Nutrition (EPIC)-Potsdam Study, Diabetes. 52, 812-7.

[35] Larsen, C.M., Faulenbach, M., Vaag, A., Volund, A., Ehses, J.A., Seifert, B., MandrupPoulsen, T. and Donath, M.Y., 2007. Interleukin-1-receptor antagonist in type 2 diabetes mellitus, N Engl J Med. 356, 1517-26.

[36] Mandrup-Poulsen, T., Pickersgill, L. and Donath, M.Y., 2010. Blockade of interleukin 1 in type 1 diabetes mellitus, Nat Rev Endocrinol. 6, 158-66.

[37] Handa, M., Vanegas, S., Maddux, B.A., Mendoza, N., Zhu, S., Goldfine, I.D. and Mirza, A.M., 2013. XOMA 052, an anti-IL-1beta monoclonal antibody, prevents IL-1betamediated insulin resistance in 3T3-L1 adipocytes, Obesity (Silver Spring). 21, 306-9.

[38] Cavelti-Weder, C., Babians-Brunner, A., Keller, C., Stahel, M.A., Kurz-Levin, M., Zayed, H., Solinger, A.M., Mandrup-Poulsen, T., Dinarello, C.A. and Donath, M.Y., 2012. Effects of gevokizumab on glycemia and inflammatory markers in type 2 diabetes, Diabetes Care. 35, 1654-62.

[39] Mohr, S., Xi, X., Tang, J. and Kern, T.S., 2002. Caspase activation in retinas of diabetic and galactosemic mice and diabetic patients, Diabetes. 51, 1172-9.

[40] Wang, C., Pan, Y., Zhang, Q.Y., Wang, F.M. and Kong, L.D., 2012. Quercetin and allopurinol ameliorate kidney injury in STZ-treated rats with regulation of renal NLRP3 inflammasome activation and lipid accumulation, PLoS One. 7.

[41] Schroder, K. and Tschopp, J., 2010. The Inflammasomes, Cell. 140, 821-832.

[42] Solle, M., Labasi, J., Perregaux, D.G., Stam, E., Petrushova, N., Koller, B.H., Griffiths, R.J. and Gabel, C.A., 2001. Altered cytokine production in mice lacking P2X(7) receptors, J Biol Chem. 276, 125-32.

[43] Tack, C.J., Stienstra, R., Joosten, L.A.B. and Netea, M.G., 2012. Inflammation links excess fat to insulin resistance: the role of the interleukin-1 family, Immunological Reviews. 249, 239-252.

[44] Stienstra, R., Joosten, L.A., Koenen, T., van Tits, B., van Diepen, J.A., van den Berg, S.A., Rensen, P.C., Voshol, P.J., Fantuzzi, G., Hijmans, A., Kersten, S., Muller, M., van den Berg, 
W.B., van Rooijen, N., Wabitsch, M., Kullberg, B.J., van der Meer, J.W., Kanneganti, T., Tack, C.J. and Netea, M.G., 2010. The inflammasome-mediated caspase-1 activation controls adipocyte differentiation and insulin sensitivity, Cell Metabolism. 12, 593-605.

[45] Goossens, G.H., Blaak, E.E., Theunissen, R., Duijvestijn, A.M., Clement, K., Tervaert, J.W. and Thewissen, M.M., 2012. Expression of NLRP3 inflammasome and T cell population markers in adipose tissue are associated with insulin resistance and impaired glucose metabolism in humans, Molecular Immunology. 50, 142-9.

[46] Koenen, T.B., Stienstra, R., van Tits, L.J., de Graaf, J., Stalenhoef, A.F., Joosten, L.A., Tack, C.J. and Netea, M.G., 2011. Hyperglycemia activates caspase-1 and TXNIP-mediated IL-1beta transcription in human adipose tissue, Diabetes. 60, 517-24.

[47] Maelfait, J., Vercammen, E., Janssens, S., Schotte, P., Haegman, M., Magez, S. and Beyaert, R., 2008. Stimulation of Toll-like receptor 3 and 4 induces interleukin-1beta maturation by caspase-8, J Exp Med. 205, 1967-73.

[48] Hornung, V., Ablasser, A., Charrel-Dennis, M., Bauernfeind, F., Horvath, G., Caffrey, D.R., Latz, E. and Fitzgerald, K.A., 2009. AIM2 recognizes cytosolic dsDNA and forms a caspase-1-activating inflammasome with ASC, Nature. 458, 514-8.

[49] Lamkanfi, M. and Dixit, V.M., 2012. Inflammasomes and their roles in health and disease, Annu Rev Cell Dev Biol. 
Table 1. Characteristics of the study group.

\begin{tabular}{|c|c|c|c|}
\hline & $\begin{array}{l}\text { NGT } \\
(n=9)\end{array}$ & $\begin{array}{l}\text { GDM } \\
(n=16)\end{array}$ & $P$ value \\
\hline Maternal age (years) & $31.0 \pm 1.7$ & $34.9 \pm 1.1$ & NS \\
\hline Maternal BMI at $\sim 12 \mathrm{wks}(\mathrm{kg} / \mathrm{m} 2)$ & $35.7 \pm 1.7$ & $34.9 \pm 1.7$ & NS \\
\hline Maternal BMI at delivery $(\mathrm{kg} / \mathrm{m} 2)$ & $38.5 \pm 1.8$ & $35.8 \pm 1.7$ & \\
\hline Gestational age at birth (weeks) & $38.5 \pm 0.2$ & $38.8 \pm 0.2$ & NS \\
\hline Fetal birth weight (g) & $3865 \pm 138$ & $3525 \pm 95$ & NS \\
\hline Fetal Gender & 5 Female; 4 & 7 Female; & \\
\hline Gravida & $3.0 \pm 0.6$ & $2.9 \pm 0.3$ & NS \\
\hline Parity & $2.1 \pm 0.3$ & $2.3 \pm 0.2$ & NS \\
\hline \multicolumn{4}{|c|}{ Maternal OGTT at $\sim 28$ weeks gestation } \\
\hline ...Fasting plasma OGTT $(\mathrm{mmol} / \mathrm{l})$ & $4.7 \pm 0.1$ & $5.6 \pm 0.3$ & $P<0.05$ \\
\hline$\ldots 1$ hour plasma OGTT (mmol/l) & $7.5 \pm 0.7$ & $10.7 \pm 0.5$ & $P<0.05$ \\
\hline ...2 hour plasma OGTT (mmol & $5.5 \pm 0.4$ & $8.8 \pm 0.4$ & $P<0.05$ \\
\hline \multicolumn{4}{|c|}{ Maternal OGTT at $\sim 6$ weeks postpartum } \\
\hline ...Fasting plasma OGTT $(\mathrm{mmol} / \mathrm{l})$ & ND & $5.0 \pm 0.4$ & \\
\hline$\ldots 1$ hour plasma OGTT $(\mathrm{mmol} / \mathrm{l})$ & ND & $6.6 \pm 0.5$ & \\
\hline ...2 hour plasma OGTT $(\mathrm{mmol} / \mathrm{l})$ & ND & $5.7 \pm 0.7$ & \\
\hline
\end{tabular}

Values represent mean \pm SEM (Student's t-test)

NS, not significant; ND, not done; OGTT, oral glucose tolerance test 


\section{FIGURE LEGENDS}

\section{Figure 1. Effect of GDM on IL-1 $\beta$ expression and release from adipose tissue}

(A) Adipose tissue was obtained from women with NGT ( $n=9$ patients), diet-controlled GDM ( $n=8$ patients), insulin-controlled GDM ( $\mathrm{n}=8$ patients) and combined GDM ( $\mathrm{n}=16$ patients) at the time of term caesarean section. IL-1 $\beta$ gene expression was normalised to GAPDH, and the fold change was calculated relative to NGT. Data is presented as mean \pm SEM. (B) Basal release of IL-1 $\beta$ from adipose tissue from women with ( $n=9$ patients) and GDM ( $n=16$ patients). Each bar represents the mean \pm SEM. $* P<0.05$ vs. NGT (Student's t-test).

Figure 2. IL-1ß inhibits the insulin signalling pathway in pregnant adipose tissue Adipose tissue was incubated in the absence or presence of $1 \mathrm{ng} / \mathrm{ml} \mathrm{IL-1 \beta}$ for $20 \mathrm{~h}$ followed by a 30 min incubation with $0.1 \mu \mathrm{M}$ insulin ( $\mathrm{n}=5$ patients) (A) Phosphorylated IRS-1 (pIRS-1) protein expression was normalised to total IRS-1, and the fold change was calculated relative to basal. Data is presented as mean \pm SEM. $* P<0.05$ vs. basal (paired sample comparison). A representative Western blot from 3 patients is also shown. (B) GLUT-4 gene expression was normalised to GAPDH, and the fold change was calculated relative to basal. Data is presented as mean \pm SEM. $* P<0.05$ vs. basal (paired sample comparison). (C) GLUT-4 protein expression was normalised to $\beta$-actin, and the fold change was calculated relative to basal. Data is presented as mean \pm SEM. $* P<0.05$ vs. basal (paired sample comparison). A representative Western blot from 3 patients is also shown. (D) $2 \mathrm{DG}$ uptake data is displayed as mean \pm SEM. ${ }^{*} P<0.05$ vs. basal $2 \mathrm{DG}$ uptake (paired sample comparison).

\section{Figure 3. Increased caspase-1 activation in adipose tissue from women with GDM}

Adipose tissue was obtained from women with NGT ( $\mathrm{n}=9$ patients), diet-controlled GDM ( $\mathrm{n}=8$ patients), insulin-controlled GDM ( $\mathrm{n}=8$ patients) and combined GDM ( $\mathrm{n}=16$ patients) at the time of 
term caesarean section. (A) Caspase-1 gene expression was normalised to GAPDH, and the fold change was calculated relative to NGT. Data is presented as mean \pm SEM. (B) Full length (p45) and active (p35 and p10) caspase-1 protein expression was analysed by Western blotting. Caspase protein expression was quantified by densitometry and the fold change was calculated relative to NGT. Each bar represents the mean \pm SEM. ${ }^{*} P<0.05$ vs. NGT (Student's t-test). Representative Western blot from 8 patients (4 GDM and 4 NGT patients) is also shown.

\section{Figure 4. LPS, palmitate and AGE-BSA induce IL-1 $\beta$ transcription via NF-кB}

Adipose tissue was incubated in the absence or presence of $50 \mu \mathrm{M}$ BAY 11-7085 for 60 min prior to the addition of $1 \mu \mathrm{g} / \mathrm{ml} \mathrm{LPS}, 0.2 \mathrm{mM}$ palmitate (PA) or $0.2 \mathrm{mg} / \mathrm{ml}$ AGE-BSA (AGE) for $20 \mathrm{~h}$ ( $\mathrm{n}=5$ patients). IL-1 $\beta$ mRNA expression was analysed by qRT-PCR and normalised to GAPDH and fold change expressed relative to basal levels. Data are presented as mean \pm SEM. $* P<0.05$ vs. LPS (one way ANOVA).

\section{Figure 5. ATP induces IL-1ß production tissues primed with LPS, palmitate and AGE-BSA}

Adipose tissue was incubated in the absence or presence of $1 \mu \mathrm{g} / \mathrm{ml} \mathrm{LPS}, 0.2 \mathrm{mM}$ palmitate (PA) or $0.2 \mathrm{mg} / \mathrm{ml}$ AGE-BSA (AGE). After $18 \mathrm{~h}$ incubation, tissues were incubated with $5 \mathrm{mM}$ ATP for a further $2 \mathrm{~h}(\mathrm{n}=4$ patients per treatment). (A,D,G) IL-1 $\beta$ mRNA expression was analysed by qRTPCR and normalised to GAPDH and fold change expressed relative to basal levels. $* P<0.05$ vs. basal (one way ANOVA). (B,E,H) The incubation medium was assayed for mature IL-1 $\beta$ concentration by ELISA. Each bar represents mean concentration \pm SEM. $* P<0.05$ vs. basal; $\S P<0.05$ vs. LPS; $\# P<0.05$ vs. PA; $* * P<0.05$ vs. AGE (one way ANOVA). (C,F,I) The incubation medium was assayed for IL-6 concentration by ELISA. Each bar represents mean concentration \pm SEM $* P<0.05$ vs. basal (one way ANOVA). 
Figure 6. Caspase-1 regulates ATP induced IL-1ß secretion in tissues primed with LPS, palmitate and AGE-BSA

Adipose tissue was incubated in the absence or presence of $10 \mu \mathrm{M}$ Ac-YVAD-CHO for $60 \mathrm{~min}$ prior to the addition of $1 \mu \mathrm{g} / \mathrm{ml} \mathrm{LPS}, 0.2 \mathrm{mM}$ palmitate (PA) or $0.2 \mathrm{mg} / \mathrm{ml}$ AGE-BSA (AGE). After $18 \mathrm{~h}$ incubation, tissues were incubated with $5 \mathrm{mM}$ ATP for a further $2 \mathrm{~h}(\mathrm{n}=4$ patients per treatment). The incubation medium was assayed for (A,C,E) mature IL-1 $\beta$ and (B,D,F) IL-6 concentration by ELISA. Each bar represents mean concentration \pm SEM. $* P<0.05$ vs. LPS (one way ANOVA).

Figure 7. ATP induces IL-1ß secretion via the $\mathrm{P} 2 \mathrm{X} 7$ receptor

Adipose tissue was incubated in the absence or presence of $10 \mu \mathrm{M} \mathrm{KN}-62$ for 60 min prior to the addition of $1 \mu \mathrm{g} / \mathrm{ml}$ LPS, $0.2 \mathrm{mM}$ palmitate (PA) or $0.2 \mathrm{mg} / \mathrm{ml}$ AGE-BSA (AGE). After $18 \mathrm{~h}$ incubation, tissues were incubated with $5 \mathrm{mM}$ ATP for a further $2 \mathrm{~h}(\mathrm{n}=4$ patients per treatment). The incubation medium was assayed for $(\mathbf{A}, \mathbf{C}, \mathbf{E})$ mature IL-1 $\beta$ and $(\mathbf{B}, \mathbf{D}, \mathbf{F})$ IL-6 concentration by ELISA. Each bar represents mean concentration \pm SEM. $* P<0.05$ vs. LPS (one way ANOVA). 
$1 \mathrm{~A}$

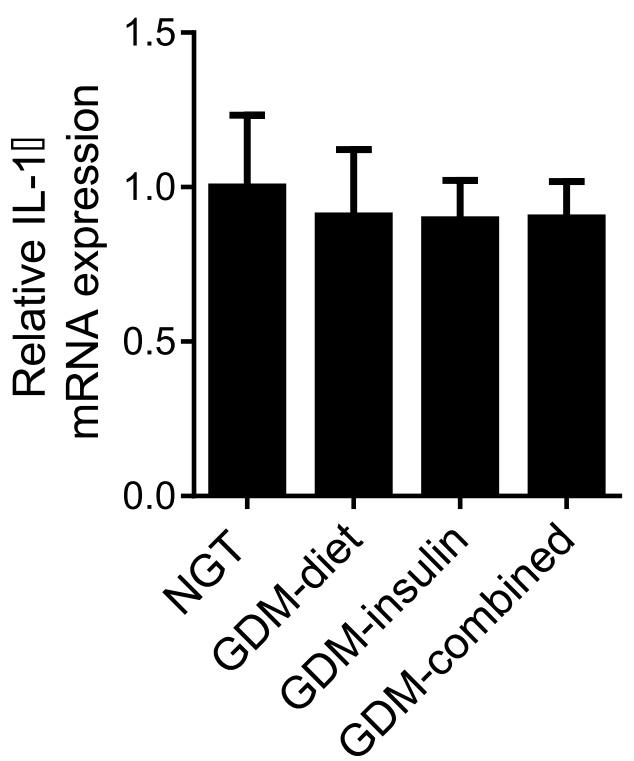

1B

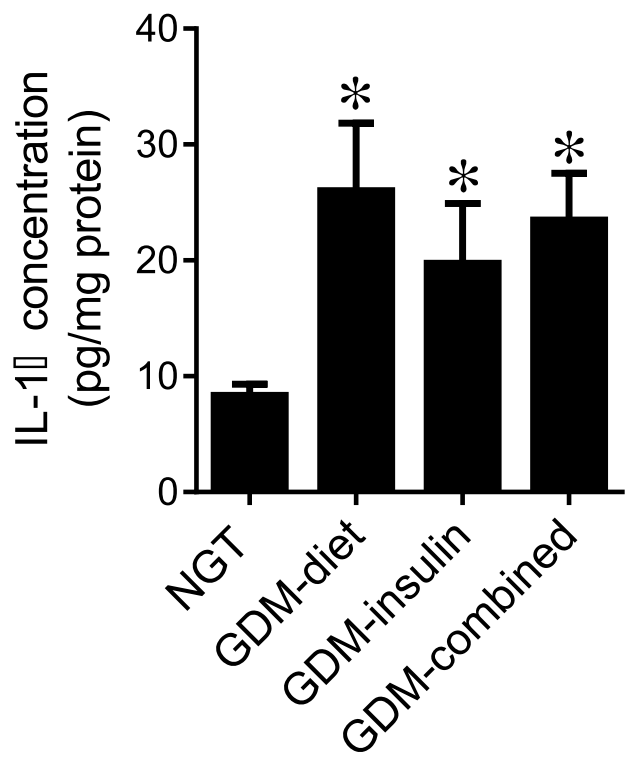



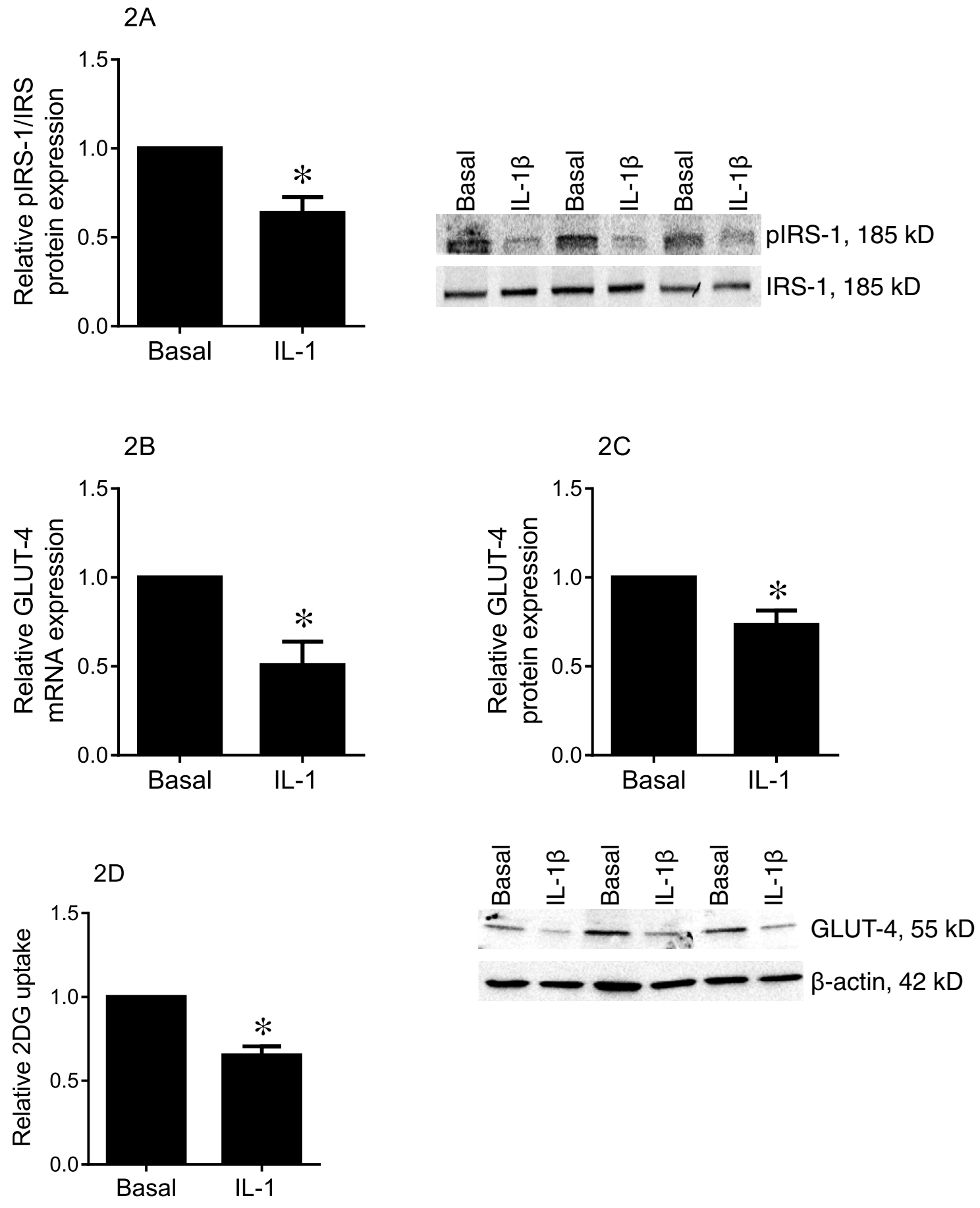

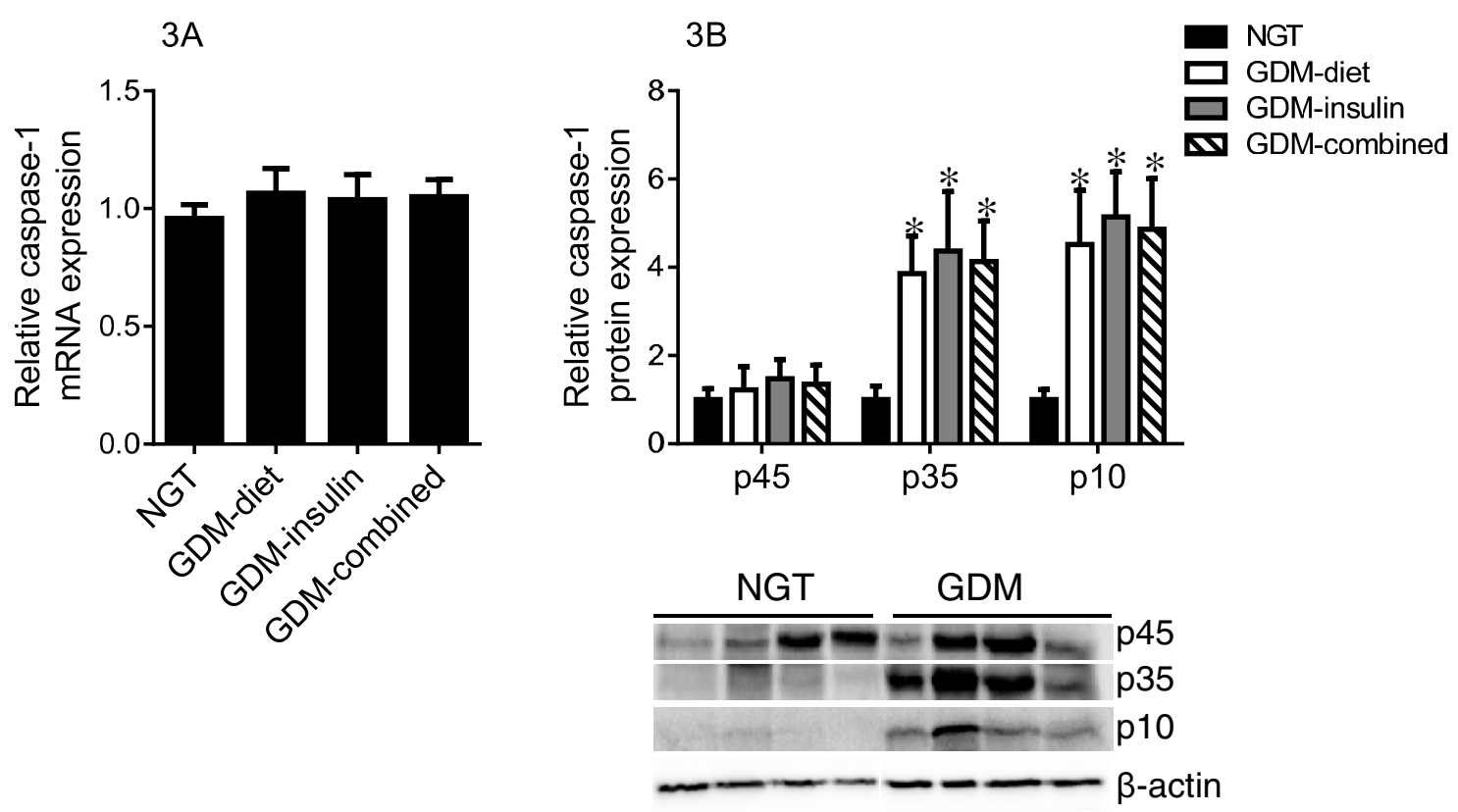

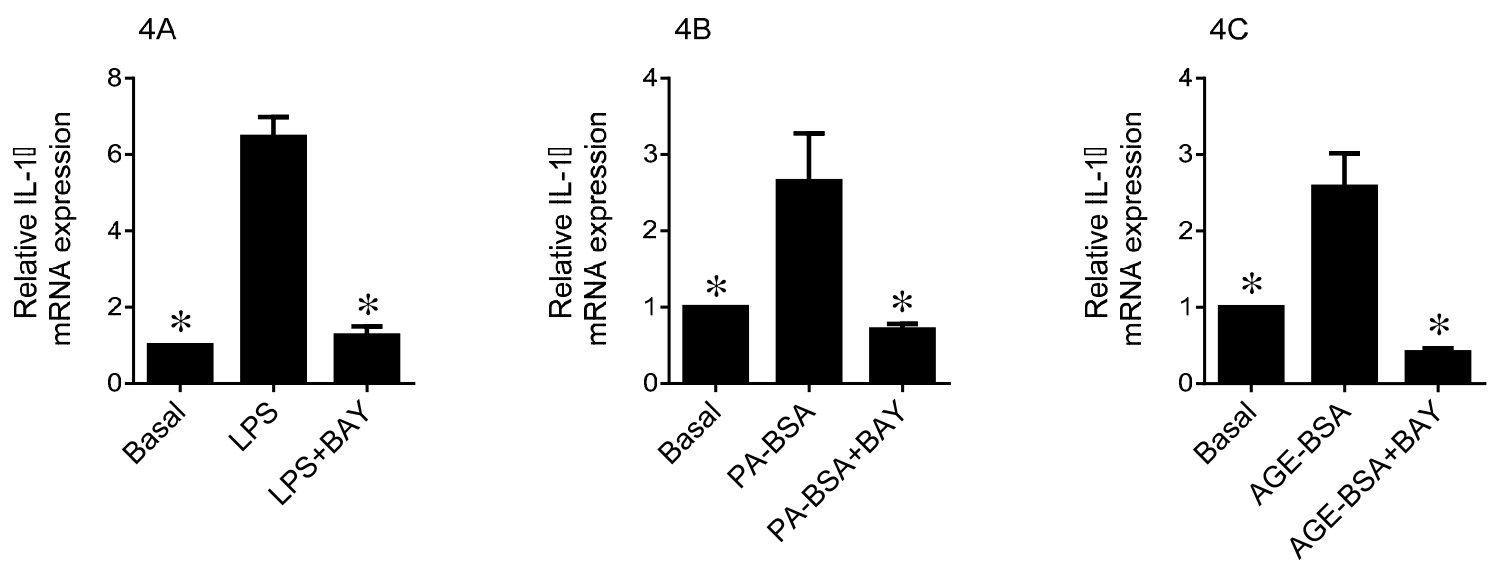
$5 \mathrm{~A}$
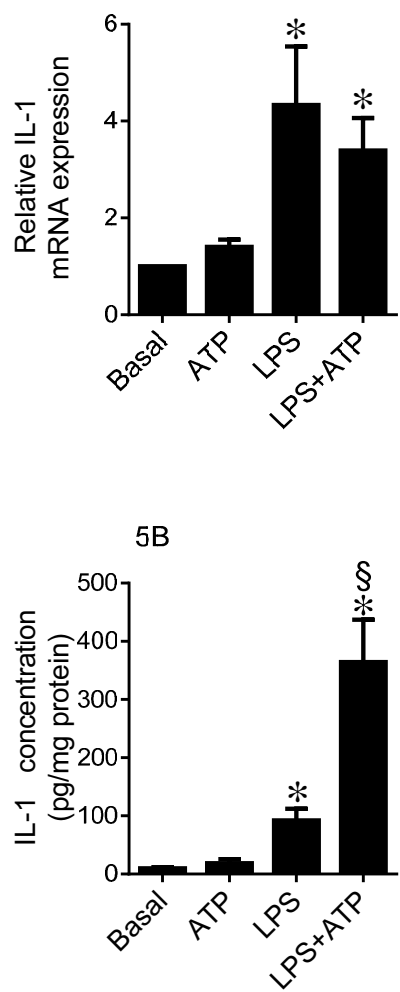

$5 \mathrm{C}$

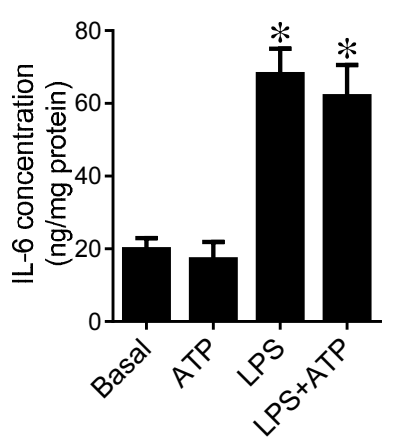

$5 \mathrm{D}$
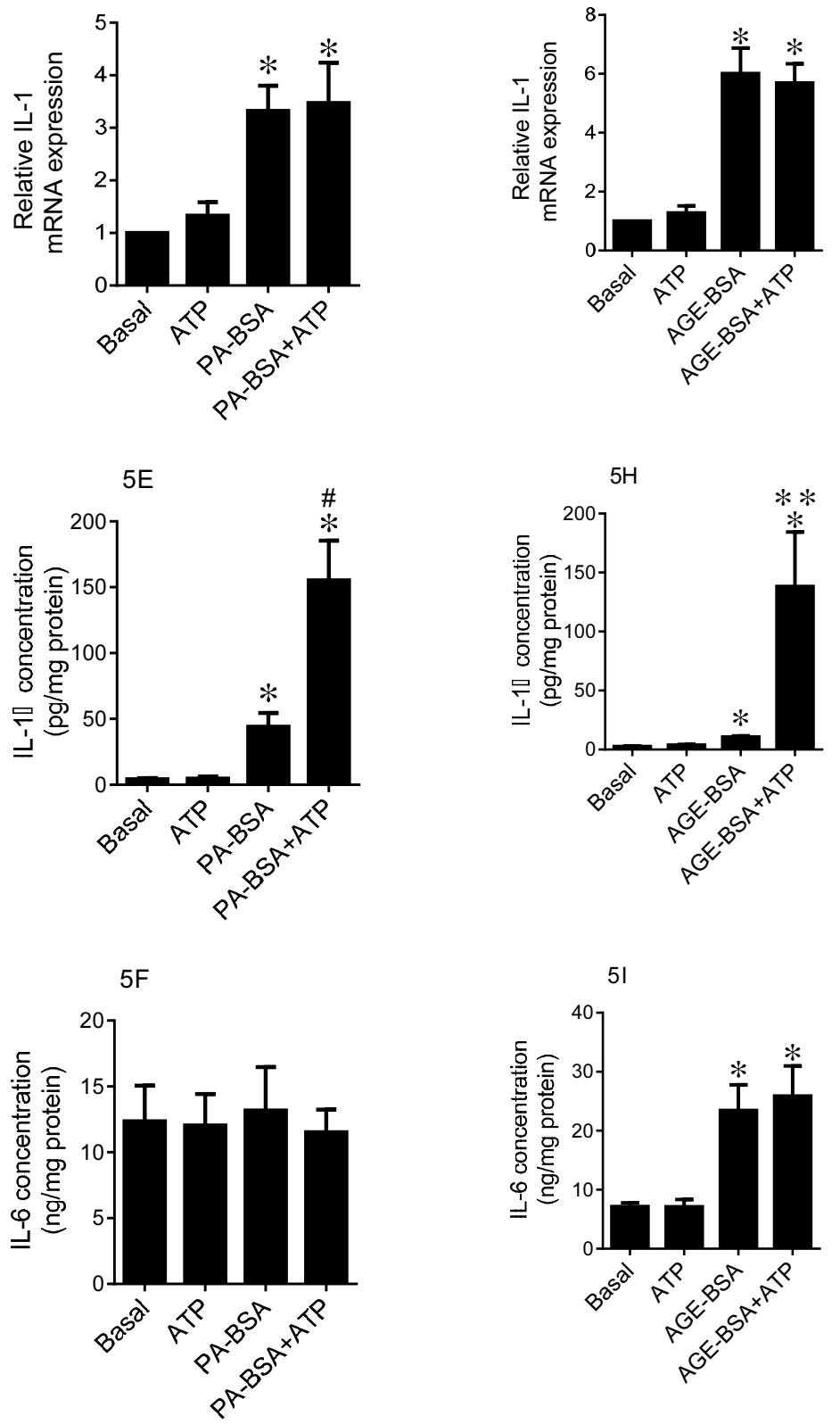

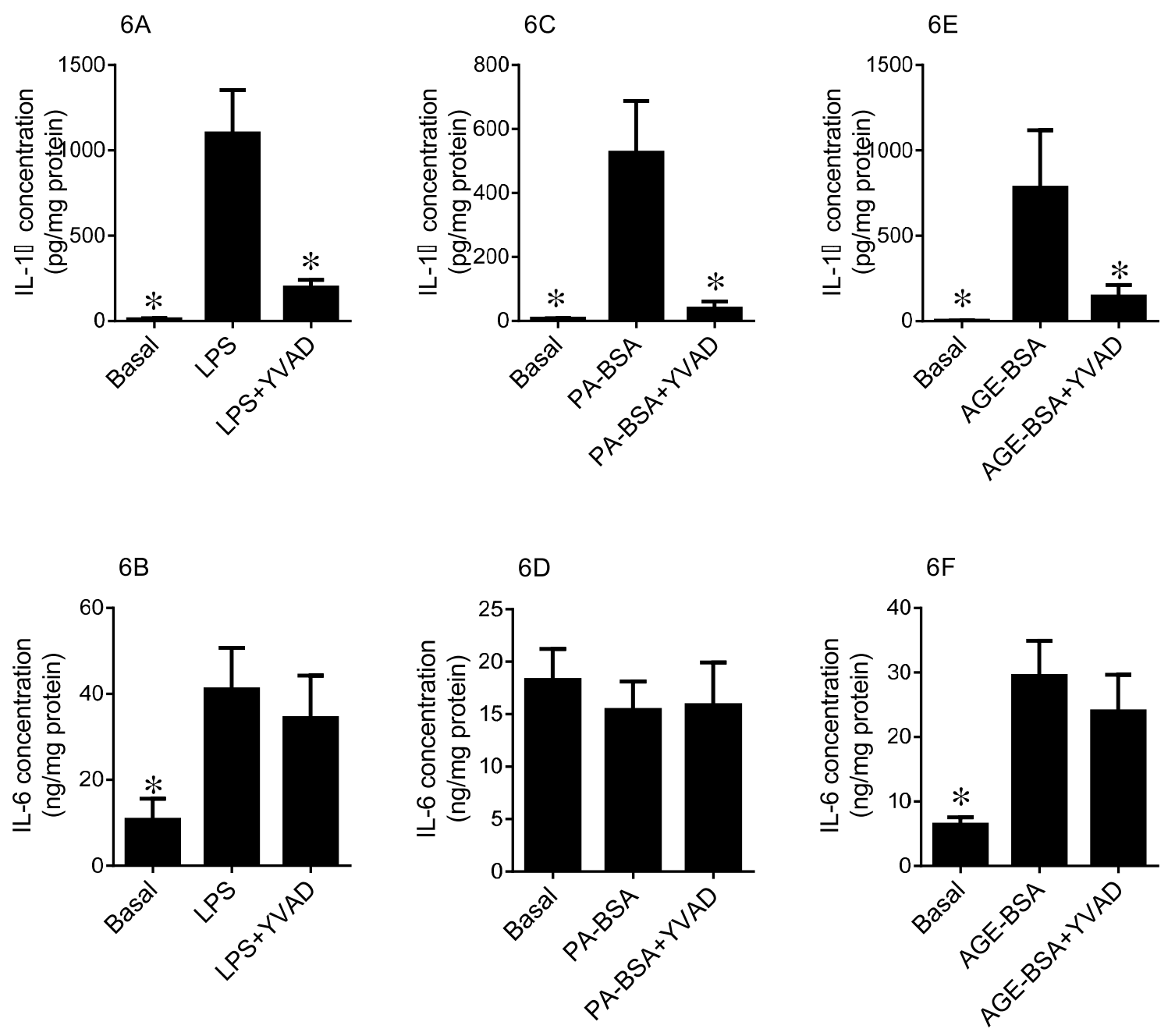

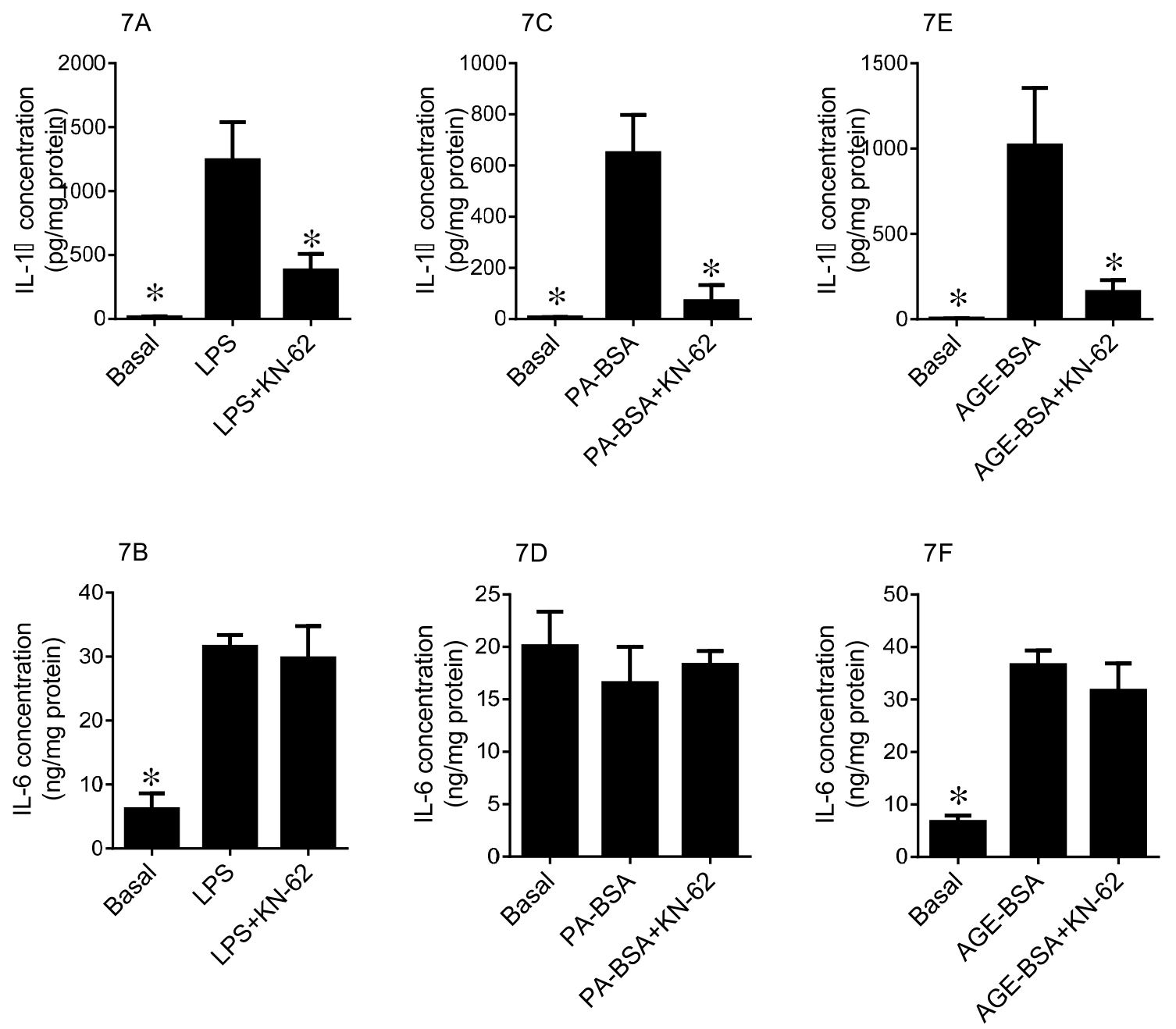


\section{HIGHLIGHTS}

- Inflammasome components caspase-1 and IL-1 $\beta$ are increased in GDM adipose tissue

- Caspase-1 mediates the maturation of IL-1 $\beta$ from pregnant adipose tissue

- IL-1 $\beta$ induces insulin resistance in pregnant adipose tissue 


\section{University Library}

\section{- M M N E R VA A gateway to Melbourne's research publications}

Minerva Access is the Institutional Repository of The University of Melbourne

Author/s:

Lappas, M

Title:

Activation of inflammasomes in adipose tissue of women with gestational diabetes

Date:

2014-01-25

Citation:

Lappas, M. (2014). Activation of inflammasomes in adipose tissue of women with gestational diabetes. MOLECULAR AND CELLULAR ENDOCRINOLOGY, 382 (1), pp.74-83. https:// doi.org/10.1016/j.mce.2013.09.011.

Publication Status:

Accepted manuscript

Persistent Link:

http://hdl.handle.net/11343/41901 